\title{
Zinc Oxide Nanoflowers Based Graphene Nanocomposite Platform for Catalytic Studies of Febuxostat
}

\author{
Rajeev Jain*', Ankita Sinha†, Dhanjai, Priyanka Karolia and Ab Lateef Khan \\ School of Studies in Chemistry, Jiwaji University, Gwalior - 474011, India \\ *E-mail: rajeevjain54@yahoo.co.in \\ †Authors have equal contribution
}

doi: $10.20964 / 2016.12 .72$

Received: 5 September 2016 / Accepted: 15 October 2016 / Published: 10 November 2016

\begin{abstract}
A novel graphene/zinc nanoflowers nano-composite modified glassy carbon electrode (GR/ZnOnFs/GCE) based electrochemical transducer system has been developed for the sensitive voltammetric analysis of a muscle relaxant drug febuxostat (FEB) in methyl alcohol at pH 6.5 Britton Robinson (BR) buffer. The developed GR/ZnOnFs/GCE) sensor was characterized by microscopic, spectroscopic and electrochemical techniques to get significant information about the morphology, composition and sensing performance of the developed electrode towards reduction of FEB. Various kinetic parameters affecting the monitored electrocatalytic response were evaluated. SWV studies shows linear response between increasing concentrations of FEB (10-400 $\mathrm{ng} \mathrm{mL}^{-1}$ ) and cathodic current with correlation coefficient $\left(\mathrm{r}^{2}\right)$ of 0.9954 with reproducibility of $3.26 \%$. The sensing utility of proposed sensor was extended to in vitro determination of the drug in pharmaceutical formulation and in waste water with an acceptable recovery and reproducibility. The fabricated (GR/ZnOnFs/GCE) sensor holds great promise for simple and sensitive quantification of febuxostat using electroanalytical techniques.
\end{abstract}

Keywords: Zinc oxide nanoflowers, Graphene, Febuxostat, Voltammetry, Nanocomposite

\section{$\underline{\text { FULL TEXT }}$}

(C) 2016 The Authors. Published by ESG (www.electrochemsci.org). This article is an open access article distributed under the terms and conditions of the Creative Commons Attribution license (http://creativecommons.org/licenses/by/4.0/). 